\title{
Klasifikasi Status Stunting Balita Di Desa Slangit Menggunakan Metode K-Nearest Neighbor
}

\author{
Tio Prasetiya ${ }^{1}$, Irfan Ali ${ }^{1}$, Cep Lukman Rohmat ${ }^{1}$, Odi Nurdiawan ${ }^{2,}$. \\ ${ }^{1}$ Rekayasa Perangkat Lunak; STMIK IKMI Cirebon; JIn Perjuangan No 10 B Majasem Kesambi \\ Kota Cirebon, telp/fax : 0231490480; e-mail : tioprasetya12@gmail.com irfanaali0.0@gmail.com \\ ceplukmanr20@gmail.com. \\ 2 Manajemen Informatika; STMIK IKMI Cirebon; Jln Perjuangan No 10 B Majasem Kesambi \\ Kota Cirebon, telp/fax 0231490480; e-mail : odinurdiawan2020@gmail.com \\ * Korespondensi: e-mail : odinurdiawan2020@gmail.com
}

Diterima: 8 Desember 2020; Review: 16 Desember 2020; Disetujui: 22 Desember 2020

Cara sitasi: Prasetiya T, Ali I, Rohmat CL, Nurdiawan O. 2020. Klasifikasi Status Stunting Balita Di Desa Slangit Menggunakan Metode K-Nearest Neighbor. Informatics for Educators and Professionals. 5 (1): 93-104.

\begin{abstract}
Abstrak : Stunting pada balita merupakan salah satu permasalahan yang sedang dialami dunia kesehatan. Kejadian ini ditandai dengan berat badan dan tinggi badan yang tidak sesuai dengan umur. Selain itu juga dipengaruhi oleh pola konsumsi makanan dan penggunaan nutrisi yang tidak disesuaikan dengan kebutuhan tubuh. Dalam mencegah kejadian Stunting kegiatan yang rutin dilakukan adalah dengan memantau perkembangan status gizi dan status tumbuh kembang balita yang dilakukan melalui kegiatan posyandu yang berlangsung pada setiap bulan. Penelitian ini menggunakan pendekatan data mining dengan algoritma K-Nearest Neighbor yaitu menggunakan perhitungan jarak euclidean, adalah sebuah metode untuk mengelompokan atau mengklasifikasikan sebuah data dari uji kelas latih pada beberapa tetangga paing dekat dengan menggunakan rumus perhitungan jarak euclidean. parameter yang dipakai pada penelitian ini didasarkan pada data antropometrik atau data pengukuran tubuh manusia, yaitu Umur, Berat Badan dan Tinggi Badan. Pengujian dilakukan dengan perhitungan manual kemudian dibuat perankingan serta implementasikan kedalam aplikasi RapidMiner.
\end{abstract}

Kata kunci : Balita Stunting, Data Mining, Klasifikasi, Metode K-Nearest Neighbor

\begin{abstract}
Stunting in toddlers is one of the problems currently being experienced by the health world. This incident is characterized by weight and height that are not age-appropriate. It is also influenced by food consumption patterns and the use of nutrients that are not adapted to the body's needs. In preventing the occurrence of Stunting activities that are routinely carried out are by monitoring the development of nutritional status and the status of growth and development of infants carried out through posyandu activities that take place every month. This study uses a data mining approach with the K-Nearest Neighbor algorithm using euclidean distance calculation, is a method for classifying or classifying a data from a training class test on several close competitors using the euclidean distance calculation formula. The parameters used in this study are based on anthropometric data or measurement data of the human body, namely Age, Weight and Height. Testing is done by manual calculation then ranking and implemented into the RapidMiner application
\end{abstract}

Keywords : Classification, Data Mining, K-Nearest Neighbor Method, Toddler Stunting

\section{Pendahuluan}

Stunting pada balita merupakan masalah gizi kronis yang sedang dialami dunia kesehatan. Anak dengan kondisi stunting mengalami kecenderungan penurunan tingkat kecerdasan, gangguan berbicara dan kesulitan dalam menangkap pembelajaran dalam metode 
yang biasa. Faktor penyebab stunting pada anak bisa di sebabkan pada saat masa kehamilan, melahirkan, menyusui atau masa nifas. seperti MPASI yang tidak mencukupi nutrisi balita[1]. Selain itu faktor kebersihan lingkungan yang buruk menjadi pemicu balita mudah terinfeksi penyakit. Polah asuh yang buruk menjadi salah satu penyebab stunting. polah asuh buruk orang tua sering disebabkan oleh faktor ibu yang terlalu muda atau kehamilan dengan jarak yang terlalu dekat Dalam hal ini Kemenkes RI berupaya untuk meningkatkan status gizi masyarakat menjadi salah satu program prioritas pembangunan kesehatan nasional yang tercantum pada sasaran pokok perencanaan pembangunan jangka menengah tahun 2015 2019 untuk menurunkan prevalansi balita stunting.

Status gizi anak wajib diketahui oleh kedua orang tua, lantaran masih banyak kasus kekurangan gizi balita di Indonesia yang belum kunjung hilang. Hal ini perlu diingat bahwa dengan melihat kondisi fisik saja tidak cukup dalam mengetahui status gizi anak [3]. Oleh karena itu pada masa ini sangat penting peran orang tua terutama ibu dalam memberikan asupan makanan pada anak. Pola makan yang diberikan sangat berpengaruh bagi tumbuh kembang anak. Karena pada masa ini dibutuhkan asupan gizi yang baik[4].

Bentuk pencapaian mahasiswa dilihat dari prestasi akademik di perguruan tinggi. Untuk menentukan predikat prestasi dilakukanlah sebuah prediksi dengan menggunakan perhitungan data mining metode k-nearst neighbor. Implementasi dari algoritma ini yang memprediksi prestasi mahasiswa bisa menghasilkan nilai akurasi sebesar $82 \%[3]$.

Penelitian menggunakan metode K-Nearst Neighbor untuk menentukan status gizi dengan melibatkan variabel tinggi badan dan berat badan, dengan menggunakan formulasi perhitungan jarak eucledian memiliki kinerja yang baik. Hal tersebut bisa dilihat dari hasil penguji kinerja system yang dihasilkan oleh jarak Eucledian dengan nilai akurasi sebesar $100 \%[4]$.

\section{Metode Penelitian}

Metodologi yang digunakan dalam penelitian dalam penerapan K-Nearest Neighbor. Dalam stunting balita. berikut Langkah-langkah penelitian yang dilakukan dalam pemecahan masalah tersebut dapat dilihat dalam diagram alir penelitian seperti pada gambar 1 .

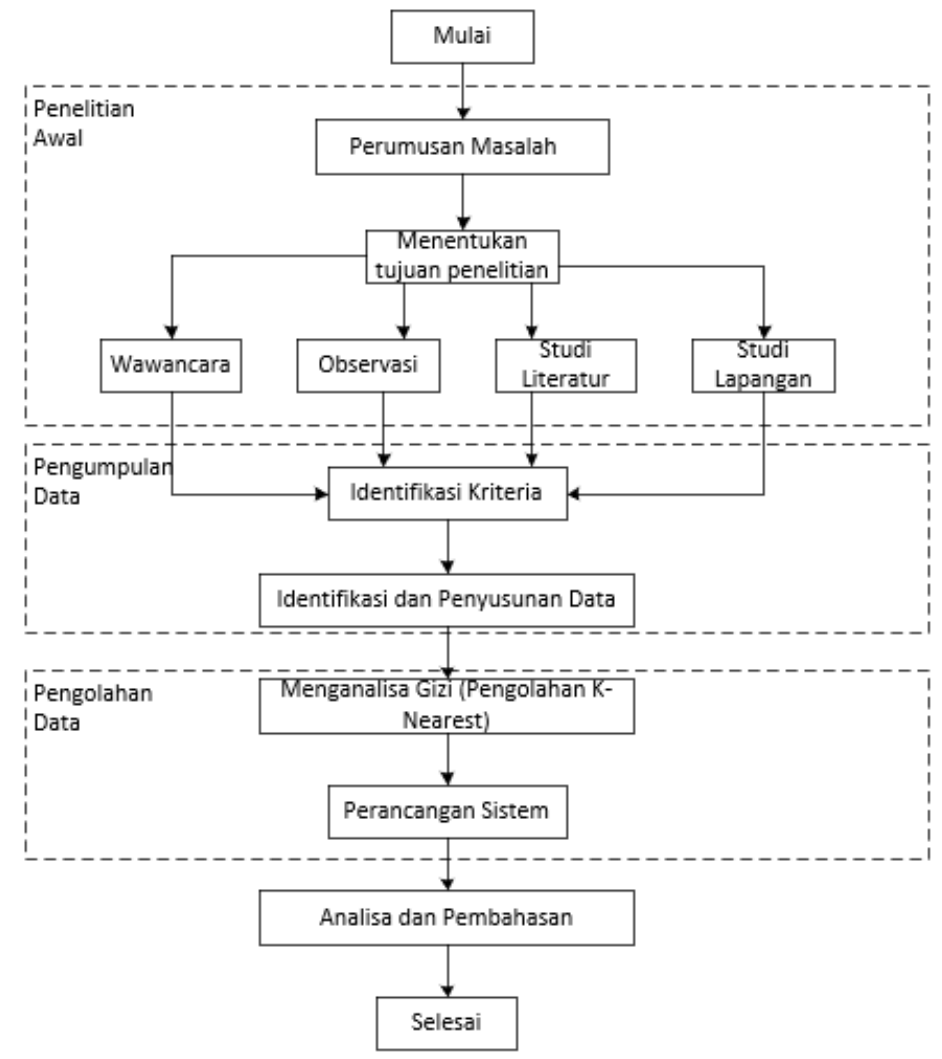

Sumber : Hasil Penelitian (2020)

Gambar 1. Diagram Alir 
Penelitian Awal, penelitian memiliki beberapa tahapan di antaranya [9] [10] : 1) Rumusan masalah, pada tahap ini merupakan tahap awal dari metodologi penelitian. Rumusan masalah di dalam penelitian yakni Bagaimana mengklasifikasi balita hanya pada status stunting menggunakan algoritma K-Nearest Neighbor. 2) Menentukan tujuan penelitian, pada tahap ini setelah diketahui masalah yang akan diselesaikan maka mentukan tujuan yang akan dicapai yaitu mendapatkan klasifikasi status balita stunting menggunakan algoritma K-Nearest Neighbor. 3) Observasi, pada tahapan ini observasi dilakukan dengan melakukan pengamatan dan pemahaman serta mencatat hal-hal penting dan mengumpulkan data-data mengenai Status Balita Stunting. 4) Wawancara, pada tahap wawancara memiliki tujuan untuk mengumpulkan informasi yang dibutuhkan dalam menerapkan metode K-Nearest Neighbor dalam menentukan status balita stunting. 5) Studi literatur, pada tahap ini akan dilakukan dengan mecari dan memahami terkait teori-teori yang akan diselesaikan dalam penelitian ini. Tahap ini dilakukan dengan memahami penelitian-penelitian terdahulu, buku, publikasi ilmiah dan internet terkait dengan Status Balita Stunting.

Pengumpulan Data, memiliki tahapan : 1) Identifikasi Kriteria, pada tahapan ini dilakukan untuk mendapatkan status balita stunting di desa slangit. 2) Identifikasi Kriteria, pada tahap ini dilakukan dengan cara memahami penelitian-penelitian terdahulu terkait kriteria-kriteria dalam menentukan balita stunting yaitu Umur balita, Berat badan, Tinggi badan balita. 3) Identifikasi dan Penyusunan Data, setelah kriteria yang akan digunakan sudah diidentifikasi, maka tahap selanjutnya adalah penyusunan instrumen yang akan digunakan untuk pengambilan data untuk penelitian ini.

Pengolahan Data, metode analisis data adalah proses penelitian yang dilakukan setelah semua data yang dibutuhkan sudah terkumpul baik berupa data primer atau data sekunder. Analisis data di sini maksudnya untuk menemukan pola umum dari data yang terkumpul dengan cara mengolah atau meringkasnya. Metode analisis data yang digunakan di penelitian ini adalah analisis deskriptif dalam menyeleksi data kuantitatif. Dalam fungsinya analisis deskriptif digunakan untuk mendeskripsikan atau menggambarkan dari data yang terkumpul dari fakta fakta yang ada, data yang dimaksud adalah data sekunder yang berupa data kuantitatif yang bentuk angka-angka dapat digunakan untuk opersi matematika, Dalam penelitian ini penyajian datanya dalam bentuk table.

Metode analisis data adalah proses penelitian yang dilakukan setelah semua data yang dibutuhkan sudah terkumpul baik berupa data primer atau data sekunder. Analisis data di sini maksudnya untuk menemukan pola umum dari data yang terkumpul dengan cara mengolah atau meringkasnya. Metode analisis data yang digunakan di penelitian ini adalah analisis deskriptif dalam menyeleksi data kuantitatif. Dalam fungsinya analisis deskriptif digunakan untuk mendeskripsikan atau menggambarkan dari data yang terkumpul dari fakta fakta yang ada, data yang dimaksud adalah data sekunder yang berupa data kuantitatif yang bentuk angka-angka dapat digunakan untuk opersi matematika, Dalam penelitian ini penyajian datanya dalam bentuk tabel.

Metode penelitian yang digunakan penulis dalam Menerapkan Algoritma K-Nearest Neighbor untuk Pengelompokan balita Stunting di Desa Slangit adalah metode dengan proses Knowledge Discovery in Databases (KDD):

Berikut tahapan-tahapan yang akan dilakukan dalam penelitian ini : Seleksi Data (Selection), selection (seleksi/pemilihan) data dari merupakan sekumpulan data operasional perlu dilakukan sebelum tahap penggalian informasi dalam Knowledge Discovery Database (KDD) dimulai. Data hasil seleksi yang akan digunakan untuk proses data mining, disimpan dalam suatu berkas, terpisah dari basis data operasional. Pemilihan Data (Preprocessing/Cleaning), proses Preprocessingmencakup adalah dengan membuang duplikasi data, mengecek data yang tidak konsisten, dan meluruskan kesalahan datanya, seperti kesalahan cetak (tipografi). Dengan dilakukan proses enrichment, yaitu proses "memperkaya" data yang sebeumnya telah ada dengan data atau informasi lainnya yang berhubungan dan diperlukan untuk Knowledge Discovery Database (KDD), contohnya pada data atau informasi eksternal. Transformasi (Transformation), pada tahap ini yang dilakukan adalah menkonversi bentuk data yang belum mempunyai entitas dengan jelas pada bentuk data yang valid atau siap untuk dilakukan prose Data Mining. Data Mining, pada tahap ini yang dilakukan adalah mempergunakan algoritma atau metode pencarian pengetahuan. Interpretasi/Evaluasi (Interpratation/Evaluation), pada tahap terakhir ini yang dilaksanakan 
adalah proses membangun keluaran yang mudah dipahami yang berasal dari proses Data Mining Pola informasi.

\section{Hasil dan Pembahasan}

Pembahasan adalah sebuah proses yang dilakukan penulis untuk menjelaskan proses penelitian yang akan dilakukan dengan menggunakan metode yang sudah ditentukan. Disini penulis akan menguraikan sistem yang akan di analisis dengan teknik data mining menggunakan Algoritma metode K-Nearst Neighbor.

Tabel 1. Data Penimbangan Posyandu

\begin{tabular}{clcccc} 
NO & \multirow{2}{*}{ NAMA BALITA } & ALAMAT & UMUR & $\begin{array}{c}\text { BERAT } \\
\text { BADAN }\end{array}$ & $\begin{array}{c}\text { TINGGI } \\
\text { BADAN }\end{array}$ \\
\hline $\mathbf{1}$ & Saaji & Posy. Putri Langit & 44 & 14,2 & 92,3 \\
\hline $\mathbf{2}$ & Runendi & Posy. Putri Langit & 41 & 12,2 & 90 \\
\hline $\mathbf{3}$ & Nizam Muazzam & Posy. Putri Langit & 46 & 11,9 & 91,4 \\
\hline $\mathbf{4}$ & Adi & Posy. Putri Langit & 38 & 10,3 & 85,2 \\
\hline $\mathbf{5}$ & Albi & Posy. Putri Langit & 48 & 11,6 & 91,8 \\
\hline $\mathbf{6}$ & M. Al lqbal & Posy. Putri Langit & 56 & 13 & 94,2
\end{tabular}

Sumber : Hasil Penelitian (2020)

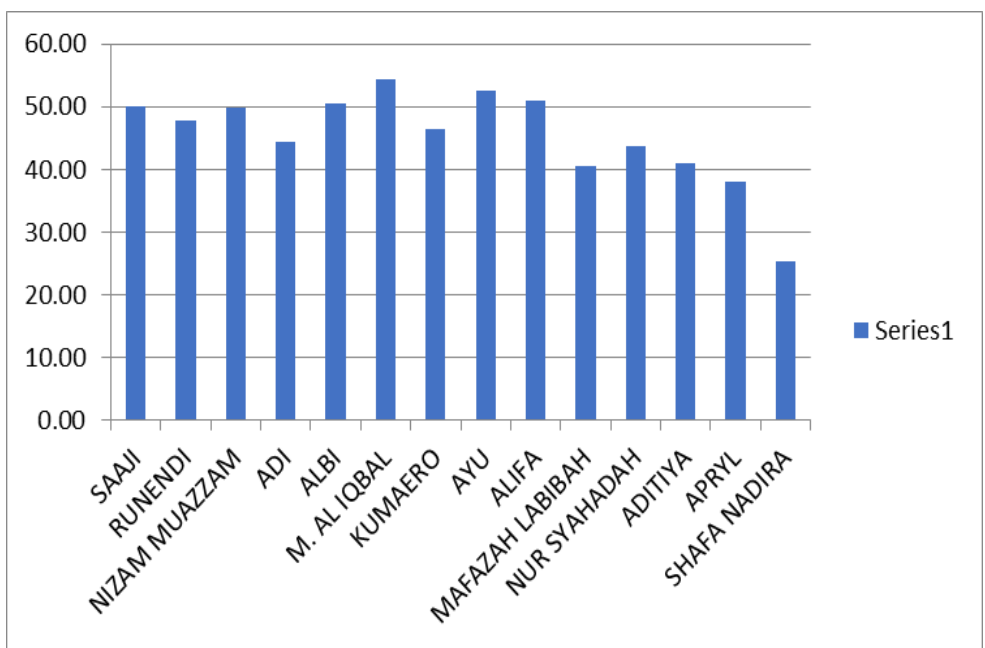

Sumber : Hasil Penelitian (2020)

Gambar 2. Data Grafik Penimbangan Posyandu

Pada Perhitungan manual digunakan sampel sebanyak 300 data untuk menghitung jarak euclidean dengan sampel 1 adalah 3 dan sampel 2 adalah 2. Langkah pertama dengan melakukan perhitungan manual yaitu dengan menghitung jarak euclidean dan menetukan nilai parameter $\mathrm{K}$ dan disini penulis menggunakan nilai parameter $\mathrm{k}=3$. Kemudian langkah kedua adalah dengan melakukan perankingan dari hasil perhitungan manual menghitung jarak dengan rumus Euclidean dengan perhitungan rumus dibawah ini :

Ingin diketahui status gizi seorang balita dengan umur 36 bulan, berat badan $12,3 \mathrm{~kg}$, tinggi badan $88 \mathrm{~cm}$. Hitung jarak antara data uji dengan sampel data yang ada dengan persamaan sebagai berikut :

$$
\mathrm{di}=f(\mathrm{p} 1-\mathrm{q} 1) 2+(\mathrm{p} 2-\mathrm{q} 2) 2+\ldots \ldots+(\mathrm{pn}-\mathrm{qn}) 2
$$

Proses Perhitungan Posyandu Putri Kimas :

$\begin{aligned} \text { Data }_{1}=\sqrt{ } f(36-32)^{2}+(12,3-10)^{2}+(88-80,8)^{2} & & =8,55 \\ \text { Data }_{2}=\sqrt{ } f(36-31)^{2}+(12,3-12,4)^{2}+(88-85)^{2} & & =91,32 \\ \text { Data }_{3}=\sqrt{ } f(36-46)^{2}+(12,3-11,9)^{2}+(88-91,4)^{2} & & =103,01 \\ \text { Data }_{4}=\sqrt{ } f(36-37)^{2}+(12,3-10)^{2}+(88-85)^{2} & & =93,24 \\ \text { Data }_{5}=\sqrt{ } f(36-45)^{2}+(12,3-10,7)^{2}+(88-86,8)^{2} & & =98,36\end{aligned}$




\begin{tabular}{|c|c|}
\hline Data $_{6}=\sqrt{ } f(36-41)^{2}+(12,3-11,2)^{2}+(88-89,5)^{2}$ & $=99,08$ \\
\hline Data $_{7}=\sqrt{ } f(36-25)^{2}+\left(12,3-10,3^{2}+(88-80,7)^{2}\right.$ & $=85,11$ \\
\hline Data $_{8}=\sqrt{ } f(36-10)^{2}+(12,3-8,3)^{2}+(88-70,4)^{2}$ & $=71,59$ \\
\hline Data $9=\sqrt{ } f(36-34)^{2}+(12,3-12,2)^{2}+(88-90,4)^{2}$ & $=97,35$ \\
\hline Data $_{10}=\sqrt{ } f(36-16)^{2}+(12,3-8,2)^{2}+(88-74,6)^{2}$ & $=76,74$ \\
\hline Data $_{11}=\sqrt{ } f(36-24)^{2}+(12,3-10)^{2}+(88-83,3)^{2}$ & $=87,26$ \\
\hline Data $_{12}=\sqrt{ } f(36-22)^{2}+(12,3-8,9)^{2}+(88-74,4)^{2}$ & $=78,09$ \\
\hline Data $_{13}=\sqrt{ } f(36-42)^{2}+(12,3-13,5)^{2}+(88-92)^{2}$ & $=102,03$ \\
\hline Data $_{14}=\sqrt{ } f(36-7)^{2}+(12,3-8)^{2}+(88-67)^{2}$ & $=67,84$ \\
\hline Data $_{15}=\sqrt{ } f(36-14)^{2}+(12,3-10,5)^{2}+(88-76,3)^{2}$ & $=78,28$ \\
\hline Data $_{16}=\sqrt{ } f(36-52)^{2}+(12,3-13)^{2}+(88-95,4)^{2}$ & $=109,43$ \\
\hline Data ${ }_{17}=\sqrt{ } f(36-11)^{2}+(12,3-9,8)^{2}+(88-71,6)^{2}$ & $=73,10$ \\
\hline Data $_{18}=\sqrt{ } f(36-50)^{2}+(12,3-17,5)^{2}+(88-103,2)^{2}$ & $=116,00$ \\
\hline Data $_{19}=\sqrt{ } f(36-2)^{2}+(12,3-3,3)^{2}+\left(88-47,2^{2}\right.$ & $=47,36$ \\
\hline Data $20=\sqrt{ } f(36-36)^{2}+(12,3-11,2)^{2}+(88-87,7)^{2}$ & $=95,46$ \\
\hline Data $_{21}=\sqrt{ } f(36-36)^{2}+(12,3-11,7)^{2}+(88-85)^{2}$ & $=93,05$ \\
\hline Data $_{22}=\sqrt{ } f(36-37)^{2}+(12,3-11,5)^{2}+(88-87,7)^{2}$ & $=95,88$ \\
\hline Data $_{23}=\sqrt{ } f(36-44)^{2}+(12,3-12,3)^{2}+(88-90,2)^{2}$ & $=101,11$ \\
\hline Data $24=\sqrt{ } f(36-49)^{2}+(12,3-14,4)^{2}+(88-93,4)^{2}$ & $=106,45$ \\
\hline Data $_{25}=\sqrt{ } f(36-42)^{2}+(12,3-11,2)^{2}+(88-90,5)^{2}$ & $=100,51$ \\
\hline Data $_{26}=\sqrt{ } f(36-20)^{2}+(12,3-9,3)^{2}+(88-74)^{2}$ & $=77,22$ \\
\hline Data $_{27}=\sqrt{ } f(36-43)^{2}+(12,3-14,5)^{2}+(88-93,5)^{2}$ & $=103,93$ \\
\hline Data $_{28}=\sqrt{ } f(36-48)^{2}+(12,3-12,3)^{2}+(88-95,5)^{2}$ & $=107,59$ \\
\hline Data $_{29}=\sqrt{ } f(36-21)^{2}+(12,3-9)^{2}+(88-76,7)^{2}$ & $=80,03$ \\
\hline Data $_{30}=\sqrt{ } f(36-55)^{2}+(12,3-16,5)^{2}+(88-204,4)^{2}$ & $=212,31$ \\
\hline Data $_{31}=\sqrt{ } f(36-25)^{2}+(12,3-9,5)^{2}+\left(88-80^{2}\right.$ & $=84,35$ \\
\hline Data $_{32}=\sqrt{ } f\left(36-36^{2}+(12,3-11,5)^{2}+(88-88,1)^{2}\right.$ & $=95,86$ \\
\hline Data $_{33}=\sqrt{ } f(36-48)^{2}+(12,3-17,8)^{2}+(88-95,2)^{2}$ & $=108,09$ \\
\hline Data $_{34}=\sqrt{ } f(36-16)^{2}+(12,3-10,3)^{2}+(88-76,5)^{2}$ & $=78,83$ \\
\hline Data $_{35}=\sqrt{ } f(36-4)^{2}+(12,3-6)^{2}+(88-59,5)^{2}$ & $=59,94$ \\
\hline Data $_{36}=\sqrt{ } f(36-45)^{2}+(12,3-10,8)^{2}+(88-88)^{2}$ & $=99,43$ \\
\hline Data $_{37}=\sqrt{ } f(36-11)^{2}+(12,3-8)^{2}+(88-72,8)^{2}$ & $=74,06$ \\
\hline Data $_{38}=\sqrt{ } f(36-9)^{2}+(12,3-9)^{2}+(88-70)^{2}$ & $=71,15$ \\
\hline Data $_{39}=\sqrt{ } f(36-28)^{2}+(12,3-11,5)^{2}+(88-84,9)^{2}$ & $=90,13$ \\
\hline Data $40=\sqrt{ } f(36-30)^{2}+(12,3-12,7)^{2}+(88-87,5)^{2}$ & $=90,13$ \\
\hline Data $_{41}=\sqrt{ } f(36-1)^{2}+(12,3-3)^{2}+(88-50)^{2}$ & $=50,10$ \\
\hline Data $_{42}=\sqrt{ } f(36-19)^{2}+(12,3-9)^{2}+(88-72,2)^{2}$ & $=75,20$ \\
\hline Data $_{43}=\sqrt{ } f(36-30)^{2}+(12,3-11)^{2}+(88-83)^{2}$ & $=88,94$ \\
\hline Data $44=\sqrt{ } f(36-80,6)^{2}+(12,3-9,3)^{2}+(88-80,6)^{2}$ & $=84,90$ \\
\hline
\end{tabular}




\begin{tabular}{|c|c|}
\hline Data $_{45}=\sqrt{ } f(36-42)^{2}+(12,3-14,3)^{2}+(88-95)^{2}$ & $=104,85$ \\
\hline Data $_{46}=\sqrt{ } f(36-22)^{2}+(12,3-10)^{2}+(88-78,1)^{2}$ & $=81,75$ \\
\hline Data $_{47}=\sqrt{ } f(36-3)^{2}+(12,3-6,5)^{2}+(88-61,4)^{2}$ & $=61,82$ \\
\hline Data $_{48}=\sqrt{ } f(36-37)^{2}+(12,3-10,4)^{2}+(88-86)^{2}$ & $=94,20$ \\
\hline Data $_{49}=\sqrt{ } f(36-36)^{2}+(12,3-11,2)^{2}+(88-87,7)^{2}$ & $=95,46$ \\
\hline Data $_{50}=\sqrt{ } f(36-30)^{2}+(12,3-10)^{2}+(88-80,6)^{2}$ & $=86,58$ \\
\hline Data $_{51}=\sqrt{ } f(36-31)^{2}+(12,3-10,4)^{2}+(88-82)^{2}$ & $=88,28$ \\
\hline Data $_{52}=\sqrt{ } f(36-38)^{2}+(12,3-10,8)^{2}+(88-86,4)^{2}$ & $=95,00$ \\
\hline Data $_{53}=\sqrt{ } f(36-45)^{2}+(12,3-10,8)^{2}+(88-88)^{2}$ & $=99,43$ \\
\hline Data $_{54}=\sqrt{ } f(36-48)^{2}+(12,3-11,7)^{2}+(88-89,2)^{2}$ & $=101,97$ \\
\hline Data $_{55}=\sqrt{ } f(36-29)^{2}+(12,3-9,7)^{2}+(88-82,5)^{2}$ & $=87,98$ \\
\hline Data $_{56}=\sqrt{ } f(36-3)^{2}+(12,3-6,5)^{2}+(88-59,5)^{2}$ & $=59,93$ \\
\hline Data $_{57}=\sqrt{ } f(36-34)^{2}+(12,3-22)^{2}+(88-98,4)^{2}$ & $=106,41$ \\
\hline Data $_{58}=\sqrt{ } f(36-7)^{2}+(12,3-8,8)^{2}+(88-67)^{2}$ & $=67,94$ \\
\hline Data $_{59}=\sqrt{ } f(36-10)^{2}+(12,3-8,3)^{2}+(88-70,4)^{2}$ & $=71,59$ \\
\hline Data $_{60}=\sqrt{ } f(36-15)^{2}+(12,3-9)^{2}+(88-74,5)^{2}$ & $=76,53$ \\
\hline Data $_{61}=\sqrt{ } f(36-23)^{2}+(12,3-10,8)^{2}+(88-80,3)^{2}$ & $=84,22$ \\
\hline Data $_{62}=\sqrt{ } f(36-32)^{2}+(12,3-12,4)^{2}+(88-91,3)^{2}$ & $=97,54$ \\
\hline Data $_{63}=\sqrt{ } f(36-36)^{2}+(12,3-10,8)^{2}+(88-86,4)^{2}$ & $=94,22$ \\
\hline Data $_{78}=\sqrt{ } f(36-58)^{2}+(12,3-17,8)^{2}+(88-109,5)^{2}$ & $=125,18$ \\
\hline Data $79=\sqrt{ } f(36-23)^{2}+(12,3-11,6)^{2}+(88-81,6)^{2}$ & $=85,57$ \\
\hline Data $80=\sqrt{ } f(36-8)^{2}+(12,3-7,5)^{2}+(88-67,1)^{2}$ & $=67,99$ \\
\hline Data $81=\sqrt{ } f(36-41)^{2}+(12,3-12,3)^{2}+(88-93,8)^{2}$ & $=103,11$ \\
\hline Data $_{82}=\sqrt{ } f(36-2)^{2}+(12,3-5,5)^{2}+(88-55,4)^{2}$ & $=55,71$ \\
\hline Data $_{83}=\sqrt{ } f(36-22)^{2}+(12,3-9,6)^{2}+(88-79,5)^{2}$ & $=83,04$ \\
\hline Data $84=\sqrt{ } f(36-16)^{2}+(12,3-8,2)^{2}+(88-74,6)^{2}$ & $=76,74$ \\
\hline Data $85=\sqrt{ } f(36-17)^{2}+(12,3-8,3)^{2}+(88-76,3)^{2}$ & $=78,61$ \\
\hline Data $86=\sqrt{ } f(36-22)^{2}+(12,3-8,9)^{2}+(88-75,6)^{2}$ & $=79,24$ \\
\hline Data $87=\sqrt{ } f(36-2)^{2}+(12,3-4)^{2}+(88-5,3)^{2}$ & $=6,93$ \\
\hline Data $88=\sqrt{ } f(36-3)^{2}+(12,3-5,2)^{2}+(88-57)^{2}$ & $=57,32$ \\
\hline Data $89=\sqrt{ } f(36-26)^{2}+(12,3-12,3)^{2}+(88-84,7)^{2}$ & $=89,45$ \\
\hline Data $_{90}=\sqrt{ } f(36-46)^{2}+(12,3-14,8)^{2}+(88-94,9)^{2}$ & $=106,49$ \\
\hline Data $91=\sqrt{ } f(36-40)^{2}+(12,3-13)^{2}+(88-94,8)^{2}$ & $=103,71$ \\
\hline Data $_{92}=\sqrt{ } f(36-36)^{2}+(12,3-11)^{2}+(88-87)^{2}$ & $=94,79$ \\
\hline Data $93=\sqrt{ } f(36-51)^{2}+(12,3-8,3)^{2}+\left(88-76,3^{2}\right.$ & $=92,15$ \\
\hline Data $_{94}=\sqrt{ } f(36-40)^{2}+(12,3-13)^{2}+(88-93)^{2}$ & $=102,07$ \\
\hline Data $95=\sqrt{ } f(36-37)^{2}+(12,3-10,7)^{2}+(88-83,3)^{2}$ & $=91,77$ \\
\hline Data $96=\sqrt{ } f(36-36)^{2}+(12,3-10,7)^{2}+(88-83,7)^{2}$ & $=91,86$ \\
\hline Data $97=\sqrt{ } f(36-51)^{2}+(12,3-11,7)^{2}+(88-9,9)^{2}$ & $=53,10$ \\
\hline
\end{tabular}




\begin{tabular}{|c|c|}
\hline Data $98=\sqrt{ } f(36-1)^{2}+(12,3-11)^{2}+(88-53,1)^{2}$ & $=53,24$ \\
\hline Data $99=\sqrt{ } f(36-7)^{2}+(12,3-3,7)^{2}+(88-67)^{2}$ & $=67,81$ \\
\hline Data ${ }_{100}=\sqrt{ } f(36-34)^{2}+(12,3-7,8)^{2}+(88-82,2)^{2}$ & $=89,67$ \\
\hline Data ${ }_{101}=\sqrt{ } f(36-12)^{2}+(12,3-8,3)^{2}+(88-70)^{2}$ & $=71,50$ \\
\hline Data ${ }_{102}=\sqrt{ } f(36-40)^{2}+(12,3-13)^{2}+(88-94,6)^{2}$ & $=103,53$ \\
\hline Data ${ }_{103}=\sqrt{ } f(36-40)^{2}+(12,3-13)^{2}+(88-94,6)^{2}$ & $=103,53$ \\
\hline Data $104=\sqrt{ } f(36-35)^{2}+(12,3-10,7)^{2}+(88-85,5)^{2}$ & $=93,00$ \\
\hline Data $_{105}=\sqrt{ } f(36-9)^{2}+(12,3-8,8)^{2}+(88-71,3)^{2}$ & $=72,40$ \\
\hline Data ${ }_{106}=\sqrt{ } f(36-20)^{2}+(12,3-9,3)^{2}+(88-79,1)^{2}$ & $=82,12$ \\
\hline Data $_{107}=\sqrt{ } f(36-40)^{2}+(12,3-13)^{2}+(88-93)^{2}$ & $=102,07$ \\
\hline Data ${ }_{108}=\sqrt{ } f(36-52)^{2}+(12,3-14,2)^{2}+(88-98,3)^{2}$ & $=112,11$ \\
\hline Data $95=\sqrt{ } f(36-37)^{2}+(12,3-10,7)^{2}+(88-83,3)^{2}$ & $=91,77$ \\
\hline Data $_{96}=\sqrt{ } f(36-36)^{2}+(12,3-10,7)^{2}+(88-83,7)^{2}$ & $=91,86$ \\
\hline Data $_{97}=\sqrt{ } f(36-51)^{2}+(12,3-11,7)^{2}+(88-9,9)^{2}$ & $=53,10$ \\
\hline Data $98=\sqrt{ } f(36-1)^{2}+(12,3-11)^{2}+(88-53,1)^{2}$ & $=53,24$ \\
\hline Data $99=\sqrt{ } f(36-7)^{2}+(12,3-3,7)^{2}+(88-67)^{2}$ & $=67,81$ \\
\hline Data ${ }_{100}=\sqrt{ } f(36-34)^{2}+(12,3-7,8)^{2}+(88-82,2)^{2}$ & $=89,67$ \\
\hline Data $_{101}=\sqrt{ } f(36-12)^{2}+(12,3-8,3)^{2}+(88-70)^{2}$ & $=71,50$ \\
\hline Data ${ }_{102}=\sqrt{ } f(36-40)^{2}+(12,3-13)^{2}+(88-94,6)^{2}$ & $=103,53$ \\
\hline Data $_{103}=\sqrt{ } f(36-40)^{2}+(12,3-13)^{2}+(88-94,6)^{2}$ & $=103,53$ \\
\hline Data $_{104}=\sqrt{ } f(36-35)^{2}+(12,3-10,7)^{2}+(88-85,5)^{2}$ & $=93,00$ \\
\hline Data $_{105}=\sqrt{ } f(36-9)^{2}+(12,3-8,8)^{2}+(88-71,3)^{2}$ & $=72,40$ \\
\hline Data ${ }_{106}=\sqrt{ } f(36-20)^{2}+(12,3-9,3)^{2}+(88-79,1)^{2}$ & $=82,12$ \\
\hline Data $_{107}=\sqrt{ } f(36-40)^{2}+(12,3-13)^{2}+(88-93)^{2}$ & $=102,07$ \\
\hline Data ${ }_{108}=\sqrt{ } f(36-52)^{2}+(12,3-14,2)^{2}+(88-98,3)^{2}$ & $=112,11$ \\
\hline Data $_{109}=\sqrt{ } f(36-56)^{2}+(12,3-13,8)^{2}+(88-99)^{2}$ & $=114,58$ \\
\hline Data $_{110}=\sqrt{ } f(36-40)^{2}+(12,3-14,6)^{2}+(88-97,8)^{2}$ & $=106,67$ \\
\hline Data $_{111}=\sqrt{ } f(36-53)^{2}+(12,3-17,4)^{2}+(88-110,6)^{2}$ & $=123,87$ \\
\hline Data $_{112}=\sqrt{ } f(36-55)^{2}+(12,3-18,4)^{2}+(88-110,7)^{2}$ & $=124,97$ \\
\hline Data ${ }_{113}=\sqrt{ } f(36-7)^{2}+(12,3-8)^{2}+(88-66,4)^{2}$ & $=67,25$ \\
\hline Data $_{114}=\sqrt{ } f(36-49)^{2}+(12,3-13,5)^{2}+(88-98,7)^{2}$ & $=111,02$ \\
\hline Data ${ }_{115}=\sqrt{ } f(36-28)^{2}+(12,3-11,6)^{2}+(88-81,2)^{2}$ & $=86,67$ \\
\hline Data $_{116}=\sqrt{ } f(36-29)^{2}+(12,3-11,8)^{2}+(88-83,3)^{2}$ & $=88,99$ \\
\hline Data $_{117}=\sqrt{ } f(36-59)^{2}+(12,3-17,3)^{2}+(88-107)^{2}$ & $=123,41$ \\
\hline Data $_{118}=\sqrt{ } f(36-19)^{2}+(12,3-11)^{2}+(88-83,1)^{2}$ & $=85,95$ \\
\hline Data $_{119}=\sqrt{ } f(36-16)^{2}+(12,3-8,3)^{2}+(88-73)^{2}$ & $=75,19$ \\
\hline Data $_{120}=\sqrt{ } f(36-39)^{2}+(12,3-15,5)^{2}+(88-96)^{2}$ & $=104,77$ \\
\hline Data $_{121}=\sqrt{ } f(36-52)^{2}+(12,3-13,3)^{2}+(88-94,4)^{2}$ & $=108,59$ \\
\hline Data $_{122}=\sqrt{ } f(36-37)^{2}+(12,3-13,3)^{2}+(88-90,8)^{2}$ & $=98,95$ \\
\hline
\end{tabular}




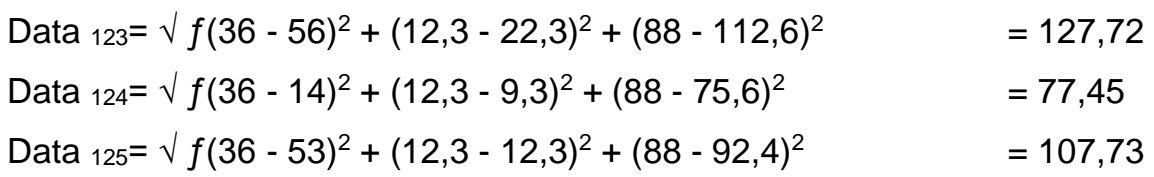
tubuh.

Perhitungan diatas merupakan perhitungan manual yang didasarkan pada indek massa

Implementasi Program

Penelitian diimplementasikan kedalam Aplikasi RapidMiner 5.3 dengan menggunakan metode K-Nearst Neighbor, yang dapat dilihat dari tahap berikut :

\section{Tampilan halaman utama software RAPIDMINER 5.3}

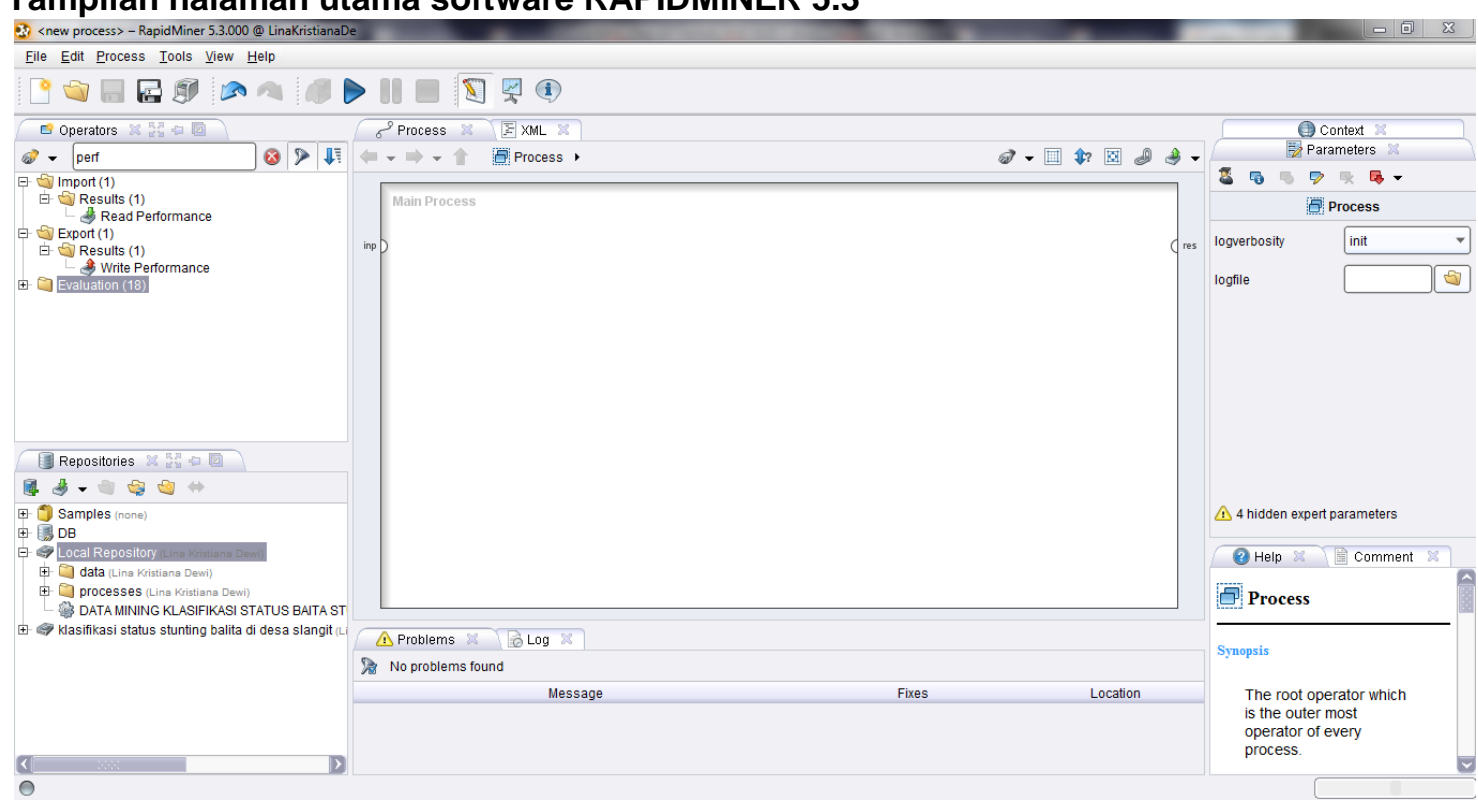

Sumber : Hasil Penelitian (2020)

Gambar 3. Tampilan model K-Means pada RapidMiner

Dari gambar 3 di atas menjelaskan tentang halaman utama atau tampilan awal ketika aplikasi RapidMiner sudah dijalankan. 
Proses input data dengan format Excel

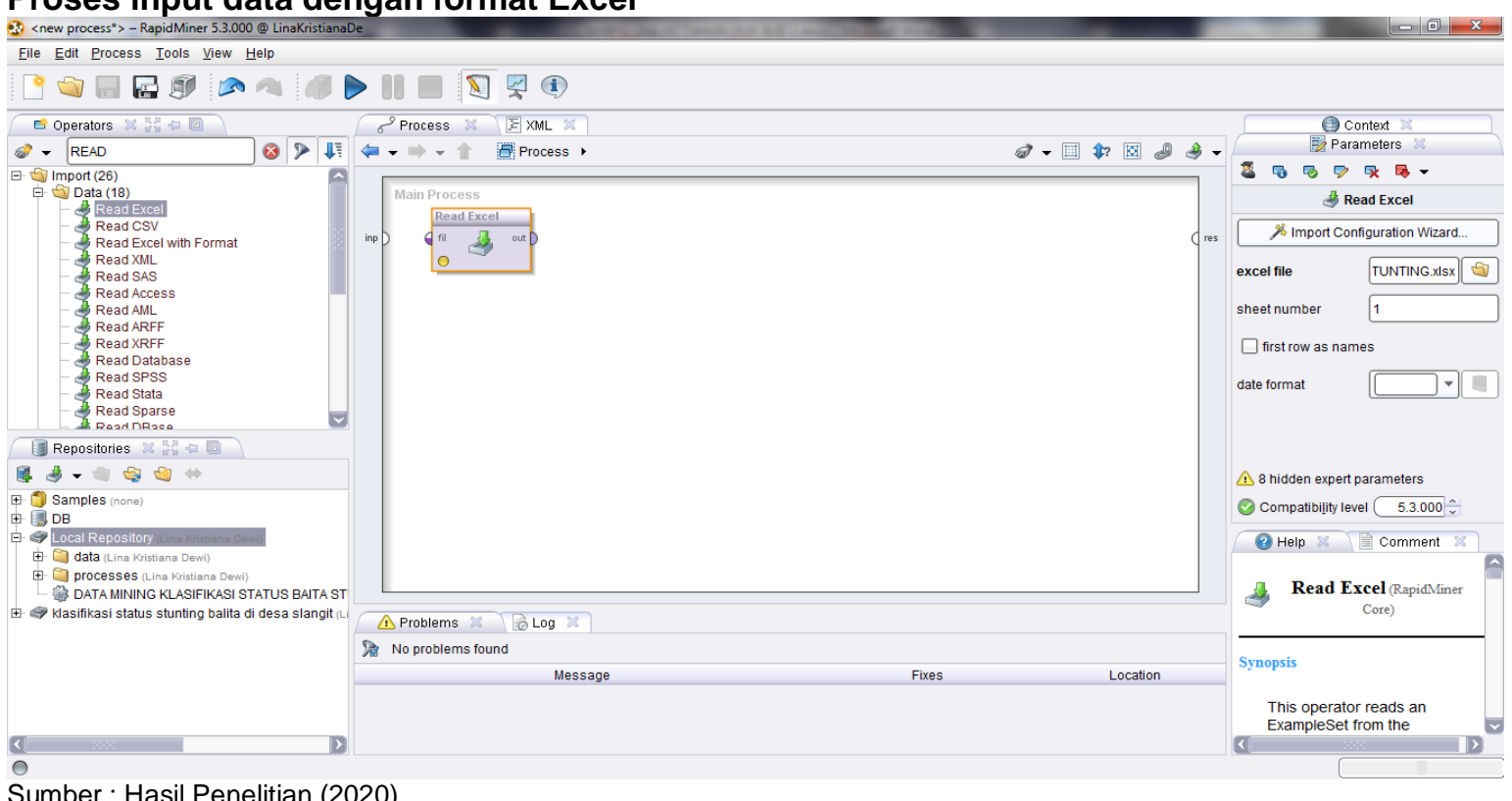

Sumber : Hasil Penelitian (2020)

Gambar 4. Tampilan Proses input data dengan format Excel

Dari gambar 4 di atas menjelaskan tentang proses penginputan data, data yang diinput bisa berbagai macam format, untuk file yang akan di uji di aplikasi ini menggunakan data dengan format excel yang sudah disiapkan.

\section{Proses validasi data}

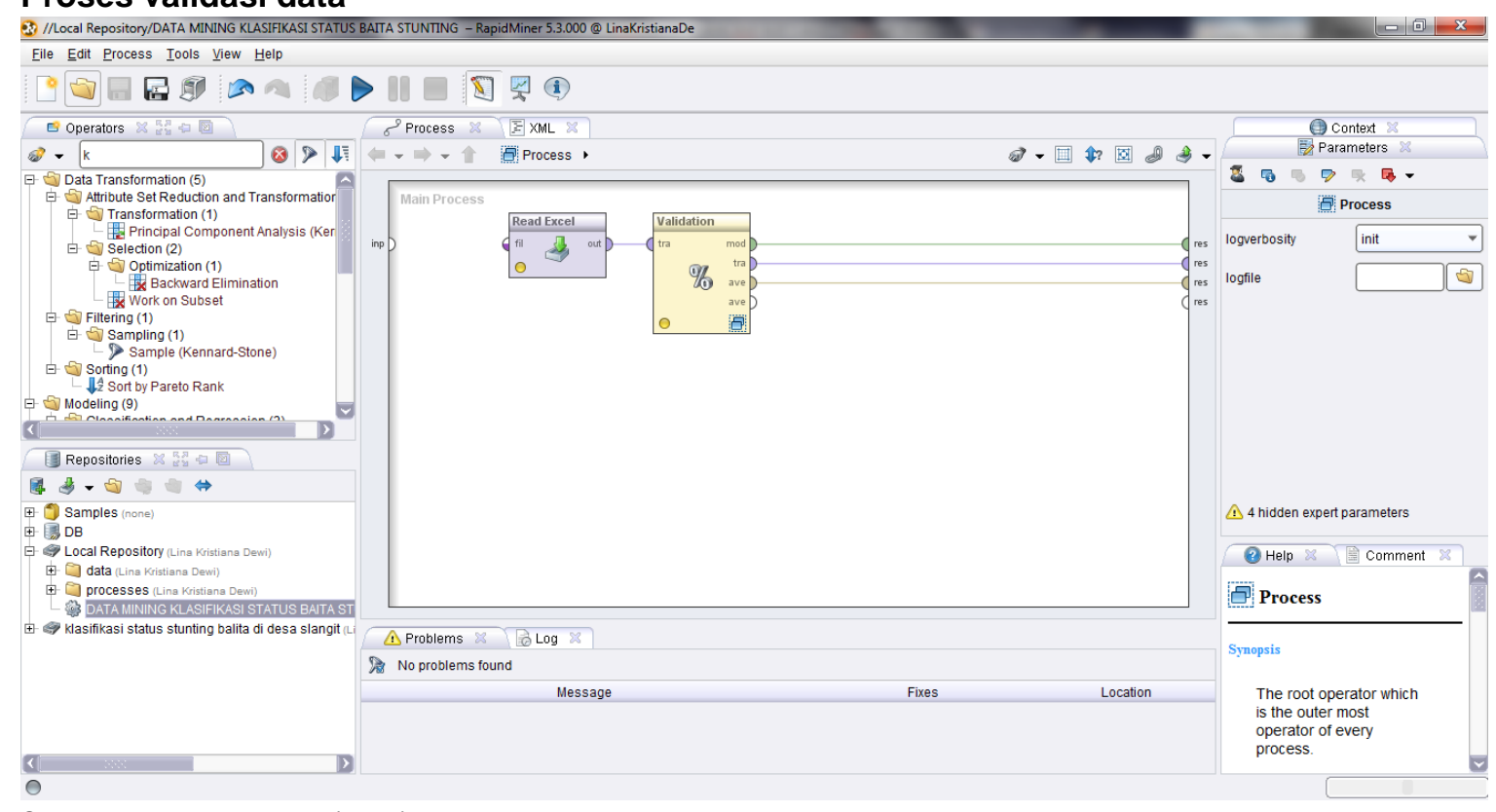

Sumber : Hasil Penelitian (2020)

Gambar 5. Proses validasi data

Dari gambar 5 di atas menjelaskan setalah data dmasukan sesuai dengan format yang dibutuhkan kemudian akan dilakukan proses validasi, proses validasi adalah proses pembuktian dari data itu sendiri. Apakah data tersebut memang valid atau mungkin bisa jadi tidak valid. 
Proses memasukan metode K-Neareest Neighbor

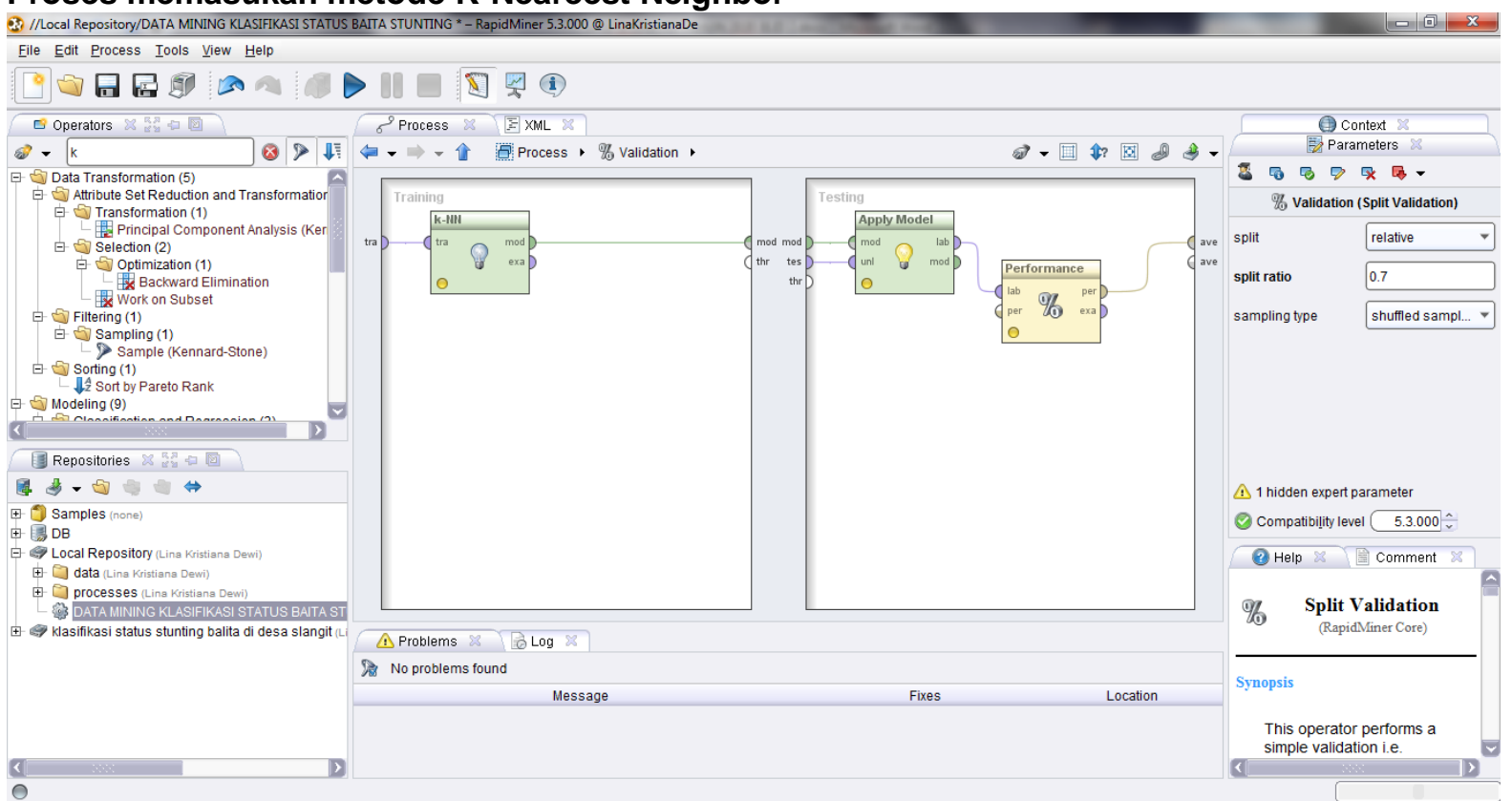

Sumber : Hasil Penelitian (2020)

Gambar 6. Proses memasukan metode K-Neareest Neighbor

Dari gambar 6 di atas menjelaskan setelah data divalidasi, kemudian selanjutnya data akan di masukkan metode sesuai dengan kebutuhannya. Dalam tahap ini penulis akan memasukkan metode K-Neareest Neighbor yang kemudian akan dibuat aplly model. Setelah itu data akan dibuat klasifikasi sesuai dengan kebutuhan penelitian. Klasifikasinya menggunakan klasifikasi perfom.

\section{Hasil akurasi data}

accuracy; 98,89\%

\begin{tabular}{|l|l|l|l|}
\hline \hline & true Kurang & true Normal & class precision \\
\hline pred. Kurang & 25 & 0 & $100.00 \%$ \\
\hline pred. Normal & 1 & 64 & $98.460 \%$ \\
\hline class recall & $96.15 \%$ & $100.00 \%$ & \\
\hline
\end{tabular}

Sumber : Hasil Penelitian (2020)

Gambar 7. Hasil akurasi data

Dari gambar 7 di atas menjelaskan setelah semua proses telah dilakukan tahap selanjutnya adalah pengecekan data, disini akan mengetahui seberapa besar tingkat akurasi data dan berapa pembagian status yang dihasilkan. Disini tingkat keakurasiannya sebesar 98,89\%. Dengan rincian akurasi yaitu Hasil Prediksi Kurang dan ternyata true Kurang sebesar 25 Data. Hasil Prediksi Kurang dan ternyata true Normal sebesar 0 Data. Hasil Prediksi Normal dan ternyata true Kurang sebesar 1 Data, dan Hasil Prediksi Normal dan ternyata true Normal sebesar 64 Data. 


\title{
KNNClassification
}

\author{
1-Nearest Neighbour model for classification. \\ The model contains 300 examples with 7 dimensions of the following classes: \\ Kurang
}

Sumber : Hasil P̈enelitian (2020)

Gambar 8. Hasil pengklasifikasian data

Dari gambar 8 di atas menjelaskan tentang proses akhir dari klasifikasi data yang menujukan proses akurasi dari data yang sudah dimasukan metode K-Neareest Neighbor kedalam aplikasi rapid miner, menghasilkan sampel data 300 balita dengan menggunakan rumus Indeks Massa tubuh (IMT). Kemudian dilakukan perhitungan dengan program RapidMiner metode KNN Classification yang menghasilkan akurasi sebesar 98,89\% dengan status NORMAL dan KURANG, maka hasil dari penelitian yang lakukan mengenai klasifikasi status balita stunting menggunakan metode K-Nearest Neighbor dengan melibatkan paramteter umur, tinggi badan dan berat badan, dapat disimpulkan bahwa penerapan metode K-Nearest Neighbor dalam pengklasifikasian status gizi balita dengan menggunakan formulasi perhitungan jarak eucledian memiliki kinerja yang baik.

\section{Kesimpulan}

Berdasarkan hasil dari penelitian yang lakukan mengenai klasifikasi status balita stunting menggunakan metode K-Nearest Neighbor dengan melibatkan paramteter umur, tinggi badan dan berat badan, dapat disimpulkan bahwa penerapan metode K-Nearest Neighbor dalam pengklasifikasian status gizi balita dengan menggunakan formulasi perhitungan jarak eucledian memiliki kinerja yang baik. Hal ini bisa dilihat penggunaan metode K-Nearest Neighbor merupakan metode klasifikasi yang dapat digunakan untuk menentukan status gizi balita.

\section{Referensi}

[1] Suharmianti Mentari and Agus Hermansyah, "Faktor-Faktor Yang Berhubungan Dengan Status Stunting Anak Usia 24-59 Bulan Di Wilayah Kerja Upk Puskesmas Siantan Hulu1"

[2] Anik Sholikah, Eunike Raffy Rustiana and Ari Yuniastuti, "Faktor - Faktor yang Berhubungan dengan Status Gizi Balita di Pedesaan dan Perkotaan," hal 9 -1 8, tahun 2017.

[3] Diyah Arini, Ayu Citra Mayasari and Muh Zul Azhri Rustam, "Gangguan Perkembangan Motorik dan Kognitif pada Anak Toodler yang Mengalami Stunting di Wilayah Pesisir Surabaya," tahun 2019.

[4] Mustakim and Giantika Oktaviani F, "Algoritma K-Nearest Neighbor Classification Sebagai Sistem Prediksi Predikat Prestasi Mahasiswa," Vol. 13, No.2, pp.195 - 202, Juni 2016.

[5] Nanda Epriliana Asmara Putri, Dahnial Syauqy and Mochammad Hannats Hanafi, "Sistem Klasifikasi Status Gizi Bayi Dengan Metode K-Nearest Neighbor Berbasis Sistem Embedded," Vol. 1, No. 9, hlm. 933-939, Juni 2017.

[6] Hamsir Saleh, Muh. Faisal and Rachmat Irawan Musa, "Klasifikasi Status Gizi Balita Menggunakan Metode K-Nearest Neighbor," Vol. 4, No. 2, 2019.

[7] Yampi R Kaesmetan and Jusrianto A Johannis "Klasifikasi Status Gizi Balita Di Kelurahan Oesapa Barat Menggunakan Metode K-Nearest Neigbor," Vol. 11, No. 1, Juni 2017.

[8] Brigita Yulia Lestari Fahik, Bertha S. Djahi and Nelci D. Rumlaklak "Data Mining Untuk Klasifikasi Status Gizi Desa Di Kabupaten Malaka Menggunakan Metode K-Nearest Neighbor," Vol. 6 No. 1, pp. 1-7, Maret 2018. 
[9] Suharmianti Mentari and Agus Hermansyah, "Faktor-Faktor Yang Berhubungan Dengan Status Stunting Anak Usia 24-59 Bulan Di Wilayah Kerja Upk Puskesmas Siantan Hulu1

[10] M. Reza Noviansyah, Tedy Rismawa and Dwi Marisa Midyanti, "Penerapan Data Mining Menggunakan Metode K-Nearest Neighbor Untuk Klasifikasi Indeks Cuaca Kebakaran Berdasarkan Data Aws (Automatic Weather Station) (Studi Kasus: Kabupaten Kubu Raya)," Volume 06, No. 2, hal 48-56, 2018.

[11] Bayu Indra Saputro, "Penerapan Sistem Klasifikasi Perpustakaan Arkeologi Di Perpustakaan Balai Arkeologi Daerah Istimewa Yogyakarta," Vol. 13 No. 2, Desember 2017.

[12] Jodi Irjaya Kartika, Edy Santoso and Sutrisno, "Penentuan Siswa Berprestasi Menggunakan Metode K-Nearest Neighbor Dan Weighted Product ," Vol. 1, No. 5, hlm. 352-360, Mei 2017.

[13] Imelda A. Muis and Muhammad Affandes, M.T, "Penerapan Metode Support Vector Machine (SVM) Menggunakan Kernel Radial Basis Function (RBF) Pada Klasifikasi Tweet," Vol. 12, No. 2, pp.189 - 197, Juni 2015. 